nych elementów struktur ustrojowych szkolnictwa, kierunków i funkcji przeprowadzanych reform oświatowych oraz trendów funkcjonowania i rozwoju szkolnictwa w podstawowych szczeblach i typach Autor dokonał analizy prównawczej systemów szkolnych kilku krajów europejskich o różnym poziomie rozwoju cywilizacyjnego takich, jak: Niemcy, Czechosłowacja, Francja, Belgia, Austria oraz Węgry, Jugosławia i Rumunia. Mimo, iż uwarunkowania ekonomiczne dla polskiej szkoły nie były wówczas zbyt korzystne wyniki analizy wykazały, że szkolnictwo polskie, zwłaszcza na szczeblu podstwowym i ogólnokształcącym, utrzymywało się na poziomie zbliżonym do czołówki europejskiej.

L. Grochowski podkreślając w rozdziale piątym (który ma znamiona podsumowania) fakt odzyskania niepodleglości przez Polskę zwraca uwage czytelnika na działania państwa polskiego zmierzającego do rozwoju, ujednolicenia, upowszechnienia i zdemokratyzowania szkolnictwa. Dużą role przypisuje w tej dziedzinie organizacjom międzynarodowego ruchu pedagogicznego, głównie działalności polegającej na wymianie myśli i doświadczeń, gdzie działania II Rzeczypospolitej wyrażały duża aktywność i znaczne zaangażowanie. L. Grochowski podkreśla, iż zaprezentowanie w świecie osiągnięć w zakresie oświaty i nauk o wychowaniu przez publikacje obcojęzyczne, wystawy szkolne, referaty wygłaszane podczas kongresów oraz różnego typu prace podejmowane na forum międzynarodowych instytucji wychowawczych i oświatowych, co za tym idzie również miedzynarodowe oceny i opinie na temat szkoty i pedagogiki polskiej stanowia wymowny oraz znaczący obraz wymiany myśli i doświadczeń pedagogicznych Polski międzywojennej z krajami europejskimi.

Przedstawione $w$ formie książkowej studia stanowia uzupełnienie bardzo szeroko podejmowanego przez wielu historyków wychowania problemu systemu edukacji w II Rzeczypospolitej uwzględniając $w$ szczególności wspólpracę międzynarodową na polu edukacji. Są tym bardziej wartościowe, iż stanowiq̨ syntezę problemów opracowanych i prezentowanych na podstawie źródel obcojęzycznych a dotąd nie publikowanych. Omawiane studia zasługuja na szczególną uwage i uznanie ponieważ podkreślają rolę i znaczenie Polski na forum międzynarodowego ruchu pedagogicznego po 123 latach niewoli.

Danuta Lech

\title{
Ludzie, wydarzenia i ośrodki polskiej logopedii, „Logopedia” 23, Wydawnictwo Polskiego Towarzystwa Logopedycznego, Lublin 1996, ss. 246
}

Tom „Logopedii” nr 23 zatytułowany $\mathbf{L u}$ dzie, wydarzenia $i$ ośrodki polskiej logopedii stanowi plon XII Zjazdu Naukowego Logopedów, który miał miejsce w Lublinie w dniach 11-13 października 1996 r. Ten zbiór, wygłoszonych na Zjeździe referatów stanowi istotny wkład w rozwój historii myśli logopedycznej, działu logopedii, który w porównaniu $\mathrm{z}$ teorią zaburzeń mowy i praktyką logopedyczną jest do tej pory najskromniej opracowany. Spośród dwudziestu jeden zamieszczonych w tomie tekstów aż w szesnastu autorzy podjęli problematykę logopedyczną $w$ aspekcie historycznym.

Typologia zaburzeń mowy. Narastanie refleksji logopedycznej to temat referatu S. Grabiasa. Autor dokonal krótkiego przeglądu klasyfikacji zaburzeń mowy zaczynając od typologii żyjącego w XVIII w. francuskiego lekarza François Boissier de Lecroi Sauvages, poprzez m.in. polskiego lekarza W. Oltuszewskiego (1855-1922), a na zakończenie przedstawił własną propozycje uwzględniającą zarazem procedure logopedyczna 
W omawianym tomie znajdziemy również tekst autorstwa M. Chęćka i I. Nowakowskiej-Kempnej poświęcony początkom historii logopedii na Górnym Śląsku, gdzie w Katowicach w 1922 r. ks. dr S. Wilczewski założył Instytut Fonetyczny.

W swym artykule Poznańska myśl logopedyczna w 33-leciu PTL K. Błachnio (wbrew tytułowi) sięgnęła do początków poznańskiej logopedii, które wiążą się z działalnością (od 1932 r.) dr med. M. Lączkowskiej. O Jej zasługach pisze także A. Obrębowski w tekście poświęconym logopedom w Klinice Foniatrii i Audiologii akademii Medycznej im. Karola Marcinkowskiego w Poznaniu.

Problematyki opieki nad dzieckiem głuchym dotyczy artykuł M. Jędrzejczaka Fakty i ́́ródla do historii powstania i pracy pierwszych w Polsce poradni rehabilitacyjnych dla dzieci gluchych.
W 23 tomie „Logopedii” czytelnik znajdzie też m.in. teksty omawiajace historię warszawskich pięcioletnich studiów logopedycznych $(\mathrm{H}$. Mierzejewska), Pomagisterskiego Studium Logopedycznego UW (M. Przybysz-Piwkowa, E. Stecko), Polskiego Towarzystwa Logopedycznego (E. Smołka), krakowskiego Zakładu Logopedii i Lingwistyki Stosowanej (J. Cieszyńska). Historię terminologii związanej z wadami wymowy przedstawiła A. Sołtys-Chmielowicz, a międzywojenną nomenklaturę dotyczącą dyscypliny zajmującej się "zboczeniami mowy" - E. Kuczyńska.

Należy z zadowoleniem powitać omawiany tom "Logopedii", którego zawartość świadczy o buđzącym się w środowisku logopedów zainteresowaniu historią swej dys. cypliny.

Ewa Kuczyńska

\section{Historyczne źródla wybranych ofert edukacyjnych w Polsce wspólczesnej. Materialy z konferencji naukowej nt. „Teoretyczne i praktyczne oferty edukacyjne we wspólczesnej pedagogice $i$ ich źródła historyczne", D. Drynda, D. Ekiert-Grabowska, W. Lusz- czuk, Wydawnictwo Uniwersytetu Śląskiego, Katowice 1996, ss. 154}

W dniach 26-27 IX 1994 r. w Uniwersytecie Śląskim w Katowicach odbyła się ogólnopolska konferencja naukowa nt. „Teoretyczne i praktyczne oferty edukacyjne we wspóczesnej pedagogice i ich źródła historyczne". Materialnym efektem tej interesującej konferencji stał się prezentowany tu tom, obejmujący 15 spośród 27 wygłoszonych wówczas referatów, komunikatów i doniesień $\mathrm{z}$ badań.

Materiały konferencyjne zebrane w omawianym tomie zostały zgrupowane w dwóch blokach tematycznych. Pierwszy został zatytulowany: „Historyczne inspiracje polskiej edukacji”, drugi zaś - „Oferty edukacyjne we współczesnej polskiej pedagogice”. Taki układ redakcji tomu jest celowy i logiczny oraz dob- rze odzwierciedla zarówno problematykę konferencji, jak i zawartość merytoryczną zamieszczonych $w$ obu częściach publikacji. $W$ pierwszej z nich znalazły się, w każdym przypadku dobrze udokumentowane źródłowo, artykuły wykazujące historyczne źródła współczesnych ofert edukacyjnych, w drugiej natomiast prace wskazujące na inspirujący charakter badań historycznych dla teraźniejszości. Dzięki przyjętej przez Zespól Redakcyjny strukturze, zamieszczone publikacje, mimo ich tematycznej różnorodności, wzajemnie się uzupełniają. Zarówno artykuły stricte historyczne, jak również większość prezentowanych w drugiej części rozważań o charakterze pedagogicznym, $z$ powodzeniem i kompetentnie ukazuja geneze 